RENATA MAKAREWICZ* - LUBLIN

\title{
SZPITAL PARAFIALNY I PRZYTULEK W GARBOWIE
}

Miejscowość Garbów jest siedzibą gminy i parafii pw. Przemienienia Pańskiego. Administracyjne należy do powiatu puławskiego w województwie lubelskim.

Nie zachowały się żadne dokumenty źródłowe, zawierające informacje o początkach garbowskiej parafii. Niemniej jednak dr Robert Wójcik, opierając się na informacjach zawartych w wielu opracowaniach dotyczących dziejów Lubelszczyzny i rozwoju sieci parafialnej na tym terenie, wyraża przypuszczenie, że parafia w Garbowie powstała na początku XII w. Wiąże to z faktem, że patronem pierwszego kościoła parafialnego w tej miejscowości był św. Wojciech, a jak wiadomo, kult tego świętego na terenach ówczesnej diecezji krakowskiej miał swoją największa popularność do końca pierwszej połowy XII w. Późniejsze świątynie przyjmowały już wezwanie św. Stanisława biskupa i męczennika, którego kanonizacja nastąpiła w $1254 \mathrm{rr}^{1}$

Najstarsza pisemna wzmianka o Garbowie zawarta jest w dziele Augusta Theinera Vetera monumenta Poloniae et Lithuaniae, w dokumencie z 1326 r. $^{2}$ Wymieniana w nim jest również wysokość dziesięciny jaką co sześć lat odprowadzał garbowski proboszcz na rzecz Stolicy Apostolskiej. Kwota ta wynosiła 2 scoty i 21 denarów $^{3}$.

Parafia garbowska przez niemal cały czas swego istnienia należała do dekanatu kazimierskiego, w diecezji krakowskiej. Po utworzeniu diecezji lubelskiej dekanat przeniesiono do Puław, a proboszczowie parafii Garbów zaczęli podlegać biskupowi lubelskiemu. Warto przy tym wspomnieć bardzo ważny czas w historii parafii, kiedy w Garbowie urzędował bp Mateusz Maurycy Wojakowski, który

* Renata Makarewicz - mgr pedagogiki, doktorantka w Instytucie Pedagogiki KUL, e-mail: renata651@interia.pl

${ }^{1}$ R. Wójcik, Historia parafii Garbów (odcinek I), „Głos Garbowa”, 1-2 (1991) s. 5.

${ }^{2}$ Archiwum Archidiecezjalne Lubelskie (dalej: AAL), sygn. Rep 60 IV b 48, Akta Kościoła Parafialnego w Garbowie; A. Theiner, Vetera monumenta Poloniae et Lithuaniae, t. 2, Roma1861, s. 262, dokument 358 .

${ }^{3}$ Tamże. 
w latach 1839-1845, pełnił dwie funkcje - proboszcza parafii Garbów i Administratora Diecezji Lubelskiej.

Kolejne istotne dla parafii wydarzenia nastąpiły w 1948 r., gdy bp Stefan Wyszyński ustanowił w Garbowie nowy dekanat ${ }^{5}$, który istnieje do dziś.

W dzieje parafii garbowskiej wpisana jest działalność różnych instytucji, które funkcjonowały przy kościelne parafialnym. Obejmowały one swą aktywnością niemal wszystkie sfery życia społecznego. Najistotniejszą funkcję pełniły jednakże, obok szkoły parafialnej, szpital parafialny oraz powstały na jego miejsce przytułek (zwany też schroniskiem dla starców).

\section{Szpital parafialny}

Historia garbowskiego szpitala parafialnego sięga lat 30. XVII wieku. Na ten fakt wskazuje Zbigniew Góralski. W swojej publikacji dotyczącej szpitali Lubelszczyzny, powołuje się on na źródła oraz na zapisy testamentowe, zgodnie z którymi instytucja ta została założona przed 1632 r. Wspomina też, że nieznany jest jej fundator ${ }^{6}$. Nadzór nad szpitalem wpisany był natomiast $\mathrm{w}$ obowiązki proboszcza i kolatora parafii ${ }^{7}$.

Szpital działający przy kościele parafialnym w Garbowie nie był dużych rozmiarów, w związku z tym mieszkało w nim od kilku do kilkunastu osób. Pensjonariusze odwdzięczali się za pobyt m.in. modlitwą za osoby wspierające działalność przytułku finansowo i materialnie oraz pracą w kościele parafialnym ${ }^{8}$.

Budynek szpitalny stał niedaleko karczmy, naprzeciwko większej sadzawki plebańskiej ${ }^{9}$. Był to dom drewniany, z dachem pokrytym gontem ${ }^{10}$. We wnętrzu budynku znajdowały się dwie izby i dwa alkierze, $\mathrm{z}$ atrium $\mathrm{w}$ środku ${ }^{11}$. Izby ogrzewane były dwoma piecami ${ }^{12}$.

Po stu latach użytkowania, w 1739 r. parafialny dom opieki dla ubogich wymagał wymiany dachu na nowy. Pod koniec XVIII w. cały budynek znajdował się w tak złym stanie, że należało przeprowadzić generalny remont. Niestety, nie znaleziono osoby, która pokryłaby koszty tego remontu ${ }^{13}$. Dom niszczał, aż do czasu, gdy probostwo w Garbowie objął biskup Mateusz Maurycy Wojakowski. Z pewnością leżało mu na sercu dobro podopiecznych szpitala, gdyż to on wła-

${ }^{4}$ R. Wójcik, Historia parafii Garbów (odcinek II), „Głos Garbowa”, 3 (1991) s. 3-4.

${ }^{5} \mathrm{http}$ :/diecezja.lublin.pl/dekanat,100273, Dekanat - garbowski (dostęp: 14.03.2011 r.)

${ }^{6}$ Z. Góralski, Szpitale na Lubelszczyźnie w okresie przedrozbiorowym, Część II, Lublin 1999, s. 33 .

${ }^{7}$ Instrukcja dla dozorów parafialnych nad domami schronień z 12(24) czerwca 1843 roku, w: Zbiór przepisów administracyjnych Królestwa Polskiego, Wydział Spraw Wewnętrznych i Duchowych, cz. 3, Zaktady dobroczynne, t. 3, Warszawa 1866, s. 369-371.

${ }^{8}$ R. Wójcik, Historia parafii Garbów (odcinek III), „Głos Garbowa”, 4 (1991) s. 5.

${ }^{9}$ AAL, sygn. Rep 60 IV b 48, Akta Kościoła Parafialnego w Garbowie; Góralski, Szpitale, cz. II, s. 33 .

${ }^{10}$ AAL, sygn. Rep 60 IV b 48, Akta Kościoła Parafialnego w Garbowie.

${ }^{11}$ Tamże; Góralski, Szpitale, cz. II, s. 33.

${ }^{12}$ AAL, sygn. Rep 60 IV b 48, Akta Kościoła Parafialnego w Garbowie.

${ }^{13}$ Góralski, Szpitale, cz. II, s. 33. 
śnie dokonał jego przebudowy, wymurowując go od środka i pokrywając nowym dachem. Koszty remontu zostały pokryte częściowo przez biskupa z jego prywatnych dochodów ${ }^{14}$. Reszta funduszy pochodziła z zapisu testamentowego uczynionego w 1803 r. na rzecz garbowskiej parafii przez Szymona Wóycickiego oraz $\mathrm{z}$ legatu Michała Eydziatowicza z roku $1834^{15}$. Potwierdzeniem przeprowadzonego remontu jest informacja z wizytacji kościoła w Garbowie z 1845 r. wskazująca na to, że szpital już od dwóch wieków mieści się w tym samym budynku ${ }^{16}$. Informacje o dalszym funkcjonowaniu garbowskiego domu dla ubogich zawiera jeden $\mathrm{z}$ artykułów opublikowanych w lubelskiej prasie, którego autor pisze o pożarze budynku szpitalnego w dniu 27 lipca 1897 r. $^{17}$

W pomoc w rozwiązaniu problemu zaangażował się wójt gminy Garbów. Po uzyskaniu aprobaty od przedstawicieli Dozoru Parafialnego, wystosował prośbę do władz zwierzchnich o wydelegowanie architekta, który wykonałby plany i sporządziłby kosztorys budowy nowego szpitala. Zapewniał przy tym o posiadaniu wystarczających funduszy na ten $\operatorname{cel}^{18}$.

W krótkim czasie zaczęły się jednakże piętrzyć poważne trudności. Wynikały one z faktu ubezpieczenia budynku szpitalnego na nazwisko właściciela majątku Garbów, którego spadkobiercy podjęli kwotę odszkodowania i nie zamierzali jej przeznaczyć na wybudowanie nowego przytułku. Nie był to jednak problem kluczowy, gdyż jak wspomniano wyżej, wójt zdążył już zgromadzić środki finansowe. Prawdziwy kłopot wystąpił w momencie wystąpienia dziedzica garbowskiego o zwrot gruntu, na którym stał szpital. Proboszcz był wprawdzie w posiadaniu dokumentów, świadczących o tym, że parcela ta była własnością parafii, jednakże dziedzic uparcie stał na stanowisku, że jest ona częścią odziedziczonego przez niego majątku i nie godził się na postawienie na niej żadnego budynku parafialnego, nie tylko domu opieki. Kompromisu nie udało się osiągnąć. W rezultacie przytułek nie powstał ${ }^{19}$.

Na kolejny dom opieki trzeba było czekać ponad trzydzieści lat - do $1932 \mathrm{r}$. Inicjatorką jego budowy była dziedziczka Lesiec, Janina z Trzcińskich Studzińska $^{20}$.

\section{Pensjonariusze szpitala i formy sprawowania opieki nad nimi}

O mieszkańcach garbowskiego przytułku wiadomo niewiele, głównie z powodu braku źródeł. W 1666 r. zanotowano, że w szpitalu garbowskim przebywało

${ }^{14}$ W. Nakonieczny, Kronika bieżaca - Garbów, „Gazeta Lubelska. Pismo Codzienne Rolniczo -Przemysłowo-Handlowe i Literackie”, 227 (1898) s. 2.

${ }^{15}$ Archiwum Państwowe w Lublinie (APL), sygn.35/115/0/2.6/8, Zespół: Rząd Gubernialny Lubelski, Akta szczegółowe tyczące się Szpitala w Garbowie; W. Nakonieczny, Garbów, „Gazeta Lubelska. Pismo Codzienne Rolniczo-Przemysłowo-Handlowe i Literackie”, 250 (1893) s. 2.

${ }^{16}$ AAL, sygn. Rep 60 IV b 48, Akta Kościoła Parafialnego w Garbowie; Góralski, Szpitale, cz. II, s. 33.

${ }^{17}$ Nakonieczny, Kronika bieżąca.

${ }^{18}$ Tamże.

${ }^{19}$ Tamże.

${ }^{20}$ AAL, sygn. Rep 60 IV b 48, Akta Kościoła Parafialnego w Garbowie. 
czterech ubogich ${ }^{21}$, w 1739 r. pod opieką proboszcza znajdowało się siedem potrzebujących jej osób, w 1790 r. przytułek zamieszkiwało czterech podopiecznych $^{22}$, a w 1792 r. było ich siedmiu ${ }^{23}$.

Pensjonariuszami szpitala w Garbowie mogły być osoby starsze, chore i kalekie, które były stałymi mieszkańcami garbowskiej gminy, i które z powodu zdrowia nie mogły podjąć pracy zarobkowej, bądź też potrzebowały pomocy w codziennych czynnościach osobistych. Byli to z reguły ludzie samotni, nieposiadający żadnej rodziny ${ }^{24}$. Niemniej jednak do przytułku przyjmowano również osoby, którym bliżsi lub dalsi krewni nie mogli zapewnić odpowiednich warunków egzystencjalnych i zaspokoić ich najważniejszych potrzeb, gdyż sami znajdowali się w trudnej sytuacji życiowej i materialnej25. W sytuacji, gdy dzieci lub krewni mieli odpowiednie warunki, aby otoczyć opieką starszych i schorowanych członków rodziny, ale nie chcieli lub obawiali się podjąć się tego zadania, mogli starać się o umieszczenie swego rodzica lub krewnego w szpitalu. Zobowiązani byli jednak płacić za jego utrzymanie. Pokreślić przy tym trzeba, że nie wolno było wyrzucić na bruk pensjonariusza, któremu nie miał kto zapewnić opieki, aby przyjąć na to miejsce osobę, której krewni byli gotowi zapłacić za jej wikt i opierunek ${ }^{26}$.

Podopiecznymi szpitala byli przeważnie ludzie dorośli, którzy ze względu na swoją sytuację życiową potrzebowali opieki ${ }^{27}$, przy czym stosowano zasadę przeznaczania osobnych izb dla mężczyzn i kobiet ${ }^{28}$. Przepisy dopuszczały też sytuacje, by w przytułku zamieszkiwały sieroty, które nie ukończyły dziewiątego roku życia. W takich przypadkach należało dostosować ogólne warunki panujące w domu szpitalnym do potrzeb dzieci ${ }^{29}$.

Sprawy opieki nad osobami przebywającymi w garbowskim szpitalu podlegały kierownictwu proboszcza, a od momentu zaanektowania Lubelszczyzny do ziem zaboru rosyjskiego, kwestię tę regulowały również przepisy administracyjne wydawane przez władze zaborcze. Zgodnie z nimi nadzór nad parafialnym domem opieki pełnił Dozór Parafialny, który z kolei zdawał sprawozdania z prowadzenia przytułku Radzie Głównej Opiekuńczej Zakładów Dobroczynnych ${ }^{30}$. Członkami Dozoru Parafialnego byli proboszcz oraz trzy osoby należące do Dozoru Kościelnego ${ }^{31}$. Stanowisko przewodniczącego przydzielano zawsze kolatorowi parafii ${ }^{32}$. W przypadku parafii garbowskiej byli to kolejni właściciele majątku Garbów: po-

\footnotetext{
${ }^{21}$ Wójcik, Historia parafii Garbów (odcinek III), s. 5.

${ }^{22}$ Góralski, Szpitale, cz. II, s. 34.

${ }^{23}$ Wójcik, Historia parafii Garbów (odcinek III), s. 5.

${ }^{24}$ Instrukcja dla dozorów parafialnych, s. 341, 349-351.

${ }^{25}$ Tamże, s. 345.

${ }^{26}$ Tamże, s. 349-351.

${ }^{27}$ Tamże, s. 373, 377-379.

${ }^{28}$ Tamże, s. 377-379.

${ }^{29}$ Tamże, s. 341.

${ }^{30}$ Tamże, s. 333.

${ }^{31}$ Tamże, s. 331-335.

${ }^{32}$ Tamże, s. 331.
} 
czątkowo przedstawiciele rodu Jezierskich ${ }^{33}$, a od roku 1904 - Broniewskich ${ }^{34}$. To właśnie członkowie Dozoru Parafialnego odpowiadali za prawidłowe organizowanie wsparcia dla osób potrzebujących pomocy (chorych, bezdomnych, starych, sierot), a jedną z form opieki nad nimi był szpital parafialny czy też przytułek ${ }^{35}$.

Obowiązek zapewnienia pensjonariuszom szpitala odpowiednich warunków spoczywał na proboszczu (nawet w latach funkcjonowania Dozoru Parafialnego). Miał on dokładać wszelkich starań, aby zaspokoić ich podstawowe potrzeby i na nim spoczywała odpowiedzialność za ich formację religijną, a co za tym idzie ich rozwój duchowy ${ }^{36}$.

Najważniejszą kwestią w codzienności szpitala garbowskiego było zapewnienie jego podopiecznym wyżywienia i odzieży. Produkty do przygotowywania posiłków pochodziły z jednego z ogrodów plebańskich ${ }^{37}$. Nowe ubranie natomiast każdy pensjonariusz otrzymywał raz $\mathrm{w}$ roku ${ }^{38}$. Nie różniło się ono od odzieży noszonej przez miejscowych chłopów. Jedynym elementem, który wyróżniał mieszkańców przytułku był czarny krzyż po prawej stronie ${ }^{39}$.

Szczególnego rodzaju sytuacją była choroba podopiecznego szpitala. W takim przypadku wzywano lekarza i oddzielano chorego od zdrowych mieszkańców przytułku, aby zapobiec ewentualnej epidemii ${ }^{40}$. W XIX w. praktykowano również umieszczenie podopiecznego w klinice medycznej, jeżeli było to konieczne ${ }^{41}$.

Jak już wspomniano, proboszcz sprawował pieczę nad życiem religijnym mieszkańców przytułku. Podkreślić należy, że byli oni zobowiązani do codziennej modlitwy za osoby wspierające działalność przytułku ${ }^{42}$ oraz posługi w kościele parafialnym ${ }^{43}$.

\section{Fundusze szpitalne}

Szpital musiał posiadać odpowiednie uposażenie, czyli majątek. Podstawą powstania i funkcjonowania szpitala parafialnego był dom mieszkalny dla osób potrzebujących opieki, zabudowania gospodarcze, a także pola orne, ogrody

${ }^{33}$ A. Chrzanowska, Historia Garbowa, w: Wracamy w przeszłość, cz. 1, red. R. Wójcik, Garbów 1999, s. 15-31; A. Chrzanowska, Garbowscy dziedzice, „Głos Garbowa”, 12 (2000) s. 8-9; R. Wójcik, Historia Cukrowni „, Garbów”, Lublin 2010, s. 26; tenże, Historia parafii Garbów (odcinek VIII), „Głos Garbowa”, 10 (1991) s. 4-5.

${ }^{34}$ R. Wójcik, Emil Bohdan Ignacy Broniewski, w: Siedziby ziemiańskie w krajobrazie ziemi garbowskiej, red H. Stępniak, Garbów 2008, s. 174-180; Wójcik, Historia Cukrowni „, Garbów”, s. 27; tenże, Historia parafii Garbów (odcinek VIII), s. 4-5; tenże, Historia parafii Garbów (odcinek IX), „Głos Garbowa”, 11 (1991) s. 3-6.

${ }^{35}$ Instrukcja dla dozorów parafialnych, s. 335-339.

${ }^{36}$ Tamże, s. 377.

${ }^{37}$ Góralski, Szpitale, cz. II, s. 34.

${ }^{38}$ Instrukcja dla dozorów parafialnych, s. 375.

${ }^{39}$ Tamże, s. 373.

${ }^{40}$ Tamże, s. 377.

${ }^{41}$ Tamże, s. 375.

${ }^{42}$ Wójcik, Historia parafii Garbów (odcinek III), s. 5.

${ }^{43}$ Tamże, Instrukcja dla dozorów parafialnych, s. 375. 
i sady. Koszty utrzymania pensjonariuszy przytułku oraz remonty budynków pokrywane były natomiast z kapitału, jaki fundator szpitala przeznaczył na ten cel.

Fundusze, z których finansowano działalność instytucji opiekuńczej jaką był szpital parafialny, uzupełnianie były środkami pieniężnymi pochodzącymi głównie z zapisów testamentowych ${ }^{44}$ i darowizn. Niemniej jednak wiele osób, które chciały wesprzeć szpital lub konkretnego pensjonariusza domu opieki, dokonywało tego poprzez ustanawianie stałych lub okresowych zasiłków pieniężnych. Środki te musiały być wykorzystane przez kierownictwo przytułku zgodnie z wolą darczyńcy ${ }^{45}$.

Duże kwoty na rzecz szpitala parafialnego w Garbowie zapisywali w swoich testamentach przeważnie ludzie bardzo zamożni. Należał do nich sędzia ziemski lubelski Jan Iżycki, który 18 sierpnia 1637 r. w dokumencie ostatniej woli obdarował ubogich pensjonariuszy garbowskiego przytułku kwota $1.000 \mathrm{z}^{46}$.

Blisko siedemdziesiąt lat później, w 1803 r., Szymon Wóycicki podjął decyzję o objęciu garbowskiej instytucji opiekuńczej pomocą finansową. Miała ona charakter stały, gdyż darczyńca w swoim legacie nakazał, aby od sumy kapitałowej w wysokości $5.000 \mathrm{zł}$ polskich (750 rubli srebrnych) corocznie wypłacano na rzecz mieszkańców szpitala określony procent. Prosił również, aby w kościele parafialnym w Garbowie modlono się za jego duszę ${ }^{47}$.

Przypuszczać należy, że kontynuatorem ostatniej woli Szymona Wóycickiego był właściciel Piotrowic Wielkich i sędzia pokoju powiatu lubartowskiego - Michał Eydziatowicz, który na mocy swego testamentu z 2 lipca 1834 r., ustanowił wieczny fundusz dla szpitala parafialnego w Garbowie. Suma zgromadzonych w nim środków finansowych wynosiła 2.000 zł (300 rubli srebrnych). Od tej kwoty co rok miały być wypłacane odsetki w wysokości $100 \mathrm{zł}$, co stanowiło 5\% wartości kapitału ${ }^{48}$. Inna część zapisu dotyczyła obdarzania szacunkiem pamięci wspomnianego wyżej Szymona Wóycickiego. Sędzia wyraził życzenie, aby raz na trzy miesiące odprawiano mszę świętą za tego dobroczyńcę mieszkańców garbowskiego domu opieki. Nabożeństwo miało być połączone z rozdawnictwem jałmużny dla ubogich ${ }^{49}$.

Należy wspomnieć też o innych zapisach testamentowych, na dużo niższe sumy. Wśród tych osób był np. prebendarz z Kurowa - Wawrzyniec Piwowicz, który w testamencie z 7 marca 1736 r. nakazał wypłacić na potrzeby mieszkańców szpitala w Garbowie 10 złotych oraz przekazać na ich rzecz po trzy korce żyta,

${ }^{44}$ Góralski, Szpitale, cz. II, s. 33; Wójcik, Historia parafii Garbów (odcinek III), s. 5.

${ }^{45}$ Instrukcja dla dozorów parafialnych, s. 357.

${ }^{46}$ Góralski, Szpitale, cz. II, s. 33.

${ }^{47}$ Nakonieczny, Garbów, „Gazeta Lubelska. Pismo Codzienne Rolniczo-Przemysłowo-Handlowe i Literackie", 250 (1893) s. 2; Nakonieczny, Kronika bieżaca, s. 2.

${ }^{48}$ APL, sygn.35/115/0/2.6/8, Zespół: Rząd Gubernialny Lubelski, Akta szczegółowe tyczące się Szpitala w Garbowie; Nakonieczny, Garbów, „Gazeta Lubelska. Pismo Codzienne Rolniczo -Przemysłowo-Handlowe i Literackie”, 250 (1893) s. 2.

${ }^{49}$ APL, sygn.35/115/0/2.6/8, Zespół: Rząd Gubernialny Lubelski, Akta szczegółowe tyczące się Szpitala w Garbowie. 
jęczmienia i tatarki ${ }^{50}$. Taka sama suma widniała w pochodzących z lat 40. XIX w. aktach spadkowych pani Moszczyńskiej. Trzykrotnie większa kwota natomiast miała być wypłacona w myśl testamentu Samuela Rogowskiego ${ }^{51}$.

Nie tylko świeccy przeznaczali swoje fundusze na działalność garbowskiego szpitala. Tą samą drogę wsparcia wybierali również proboszczowie parafii w Garbowie. Wymienić tu należy ks. Mikołaja Sługockiego, który wyasygnował na potrzeby przytułku kwotę 1.540 złotych polskich ${ }^{52}$. Następnie w swoim testamencie z 1666 r. zapisał na jego rzecz sumę 400 złotych polskich ${ }^{53}$. Fundusz ten zabezpieczono na majątkach Wielki Las i Glinnik, a dokonał tego Quasimodo Bogusław Zdębski (lub Zbąski) ${ }^{54}$. Ponad sto lat później, 15 maja 1779 r., suma ta została przeniesiona na dobra radzyńskie, ze względu na sprawy dziedziczne rodu Potockich. Warto jednak wspomnieć, że prowizja od tego kapitału wypłacana była kolejnym proboszczom garbowskim aż do 1790 r., kiedy wynosiła 14 z ${ }^{55}$.

$Z$ pewnością środki finansowe, jakie darczyńcy zapisywali w testamentach na rzecz szpitala parafialnego nie zawsze były na tyle duże, aby można było z nich pokryć koszty związane z jego prowadzeniem i zaspokoić najważniejsze potrzeby jego mieszkańców ${ }^{56}$. Ogromne znaczenie miała wówczas pomoc parafian, którzy za swój chrześcijański obowiązek i przejaw miłosierdzia uważali dzielenie się swoimi dobrami z potrzebującymi. Wsparcie to miało zarówno formę jałmużny pieniężnej, jak również darów w postaci żywności, odzieży i sprzętów niezbędnych w gospodarstwie domowym i rolnym ${ }^{57}$. Uzupełnieniem tej pomocy były datki wrzucane do skarbon wystawianych w kościele, które były wybierane raz na trzy miesiące ${ }^{58}$.

Trudno stwierdzić, czy dochody pochodzące z funduszy i kapitałów zapisanych przez dobroczyńców na rzecz działalności szpitala w Garbowie były wystarczające w stosunku do potrzeb podopiecznych tej instytucji. Wiadomo na przy$\mathrm{kład}$, że w latach 60. XIX w. proboszcz co roku otrzymywał z tytułu legatów 35 rubli srebrnych i 92 kopiejki, którą to sumę przeznaczał w całości na przytułek i jego mieszkańców ${ }^{59}$. Brakuje jednakże informacji odnośnie do tego, czy we wspomnianym okresie, w przypadku garbowskiego szpitala była to adekwatna kwota, aby zapewnić pensjonariuszom odpowiednie warunki egzystencjalne.

50 Tamże.

${ }^{51}$ Góralski, Szpitale, cz. II, s. 34.

${ }^{52}$ AAL, sygn. Rep 60 IV b 48, Akta Kościoła Parafialnego w Garbowie; R. Wójcik, Historia parafii Garbów (odcinek VII), „Głos Garbowa”, 9 (1991) s. 5-6.

${ }^{53}$ Góralski, Szpitale, cz. II, s. 33; H. Stępniak, Nasza mała ojczyzna - Garbowszczyzna, s. 53; Wójcik, Historia parafii Garbów (odcinek III), s. 5.

${ }^{54}$ Góralski, Szpitale, cz. II, s. 33; Wójcik, Historia parafii Garbów (odcinek III), s. 5.

${ }^{55}$ Góralski, Szpitale, cz. II, s. 33.

${ }^{56}$ Tamże.

${ }^{57}$ Instrukcja dla dozorów parafialnych, s. 361-363.

58 Tamże, s. 365.

59 Nakonieczny, Garbów, „Gazeta Lubelska. Pismo Codzienne Rolniczo-Przemysłowo-Handlowe i Literackie", 250 (1893) s. 2. 


\section{Przytułek}

Po pożarze starego szpitala parafialnego, który miał miejsce w 1897 r. nie udało się w krótkim czasie wybudować nowego domu opieki. Jak już wspomniano, głównym problemem był brak odpowiedniego placu, na którym mógłby postać przytułek $^{60}$. Niestety nie istnieją żadne zapiski odnośnie do losu podopiecznych szpitala, którzy w tak dramatycznych okolicznościach stracili dach nad głową.

Przez kolejnych 35 lat przy kościele parafialnym w Garbowie nie funkcjonował żaden dom schronienia. Zasadnicza zmiana nastąpiła w 1932 r. za sprawą właścicielki majątku Leśce - Janiny Franciszki z Trzcińskich Studzińskiej, która postanowiła wyasygnować dużą kwotę pieniężną na utworzenie nowego przytuk$\mathrm{ku}^{61}$.

W pierwszym rzędzie postanowiono znaleźć na terenie gminy Garbów odpowiedniej wielkości posesję z budynkiem mieszkalnym. Proboszcz Dominik Przyłuski i Janina Studzińska wybrali dużą parterową willę, zbudowaną we włoskim stylu. Posiadłość ta należała do Teresy i Marii Siemiątkowskich - spadkobierczyń hrabiny Zofii Potockiej ${ }^{62}$. Nie interesowały się one jednakże zbytnio odziedziczonym domem i nie dokonywały żadnych niezbędnych remontów, skutkiem czego budynek popadał w ruinę ${ }^{63}$. Postanowiono zatem odkupić go od właścicielek i przeznaczyć go na potrzeby ubogich i chorych parafian ${ }^{64}$.

Umowa kupna-sprzedaży posiadłości zwanej kolonia Garbów - hrabiny Potockiej została zawarta dnia 9 kwietnia 1932 pomiędzy Teresą i Marią Siemiątkowskimi a rzymskokatolicką diecezją lubelską. Środki pieniężne w wysokości 2.500 zł na zakup domu i działki wielkości około 1 hektara przekazała - zgodnie z deklaracją - dziedziczka dóbr Leśce ${ }^{65}$. Akt rejentalny natomiast został sporządzony w Lublinie w biurze notariusza Stefana Smólskiego ${ }^{66}$.

$\mathrm{Na}$ wyremontowanie willi potrzebne były duże fundusze, którymi proboszcz nie dysponował. Za zgodą biskupa lubelskiego zdecydował się więc na odsprzedanie części gruntu właścicielowi Garbowa - Zygmuntowi Broniewskiemu. W ten sposób uzyskał środki pieniężne, które mógł przeznaczyć na materiały budowlane i zapłatę dla robotników ${ }^{67}$. $\mathrm{Z}$ pomocą finansową wystąpił też wówczas brat garbowskiego dziedzica - Mieczysław Broniewski - przedsiębiorca i właściciel sąsiednich Przybysławic ${ }^{68}$.

\footnotetext{
${ }^{60}$ Tenże, Kronika bieżaca, s. 2.

${ }^{61}$ Archiwum Multimedialnej Izby Tradycji w Garbowie (dalej: AMIT), sygn. 1/02/0014/1, Akta dotyczące Schroniska dla Starców w Garbowie.

${ }^{62}$ AAL, sygn. Rep 60 IV b 48, Akta Kościoła Parafialnego w Garbowie; I. Poleszak, Z okruchów pamięci. Historia przytutku parafialnego w Garbowie, „Głos Garbowa”, 1-2 (2009) s. 10; M. Suszkiewiczowa, Szukamy śladów tych, którzy przed nami trudzili się dla Polski i ludu Garbowa, Proboszcz - Dominik Przytuski, „Głos Garbowa”, 7 (2002) s. 13-15.

${ }^{63}$ Suszkiewiczowa, Szukamy śladów, s. 13-15.

${ }^{64}$ AAL, sygn. Rep 60 IV b 48, Akta Kościoła Parafialnego w Garbowie.

${ }^{65}$ Tamże.

${ }^{66}$ AMIT, sygn. 1/02/0014/1, Akta dotyczące Schroniska dla Starców w Garbowie.

${ }^{67}$ AAL, sygn. Rep 60 IV b 48, Akta Kościoła Parafialnego w Garbowie.

${ }^{68}$ Poleszak, $Z$ okruchów pamięci, s. 10.
} 
Powstała instytucja otrzymała oficjalnie nazwę Schronisko dla Starców $w$ Garbowie i była własnością garbowskiej parafii. Nadzór nad przytułkiem powierzono proboszczowi, a jego obowiązki w tym zakresie przejmowali kolejni księża obejmujący probostwo w Garbowie ${ }^{69}$. Wspomnieć w tym miejscu trzeba, że życzenie właścicielki Lesiec dotyczące przeznaczenia domu opieki wyłącznie na cele charytatywne ${ }^{70}$, było zawsze respektowane, w związku z czym schronienie i wsparcie w tej instytucji znajdowali wyłącznie najbiedniejsi i najbardziej osamotnieni mieszkańcy garbowskiej parafii.

\section{Budynki i grunty przytułku}

Przytułek funkcjonujący przy kościele parafialnym w Garbowie, mieścił się, jak już wspomniano, w drewnianej willi. Był to duży budynek, wewnątrz którego znajdowało się dwanaście pokoi, dwa korytarze i dwie sutereny ${ }^{71}$.

$\mathrm{W}$ momencie powstania domu opieki na wyposażeniu gospodarstwa znajdowały się: studnia na korbę, umiejscowiona na podwórzu murowana piwnica wielkości $21 \mathrm{~m}^{2}$ oraz zabudowania gospodarcze w postaci małego drewnianego chlewika i niewielkiej drewnianej obory. W latach późniejszych, wybudowano drewnianą szopę o powierzchni $20 \mathrm{~m}^{272}$.

$\mathrm{Na}$ terenie przynależnym do przytułku znajdowały się półtora morgi pola ornego, sad owocowy ${ }^{73}$ oraz ogród o powierzchni 70 arów $^{74}$.

Przez siedem lat, aż do wybuchu drugiej wojny światowej, warunki bytowe mieszkańców przytułku utrzymywane były na dobrym poziomie. Niestety okres okupacji niemieckiej nie sprzyjał dokonywaniu chociażby najdrobniejszych napraw i konserwacji. W rezultacie po zakończeniu wojny okazało się, że willa znajdowała się w bardzo złym stanie technicznym. Aby nie dopuścić do zawalenia się budynku proboszcz przeznaczył pewną kwotę pieniędzy z budżetu Parafialnego Oddziału „Caritas” na drobne prace naprawcze. Przytułek wymagał jednakże generalnego remontu. Sprawą najważniejszą było pokrycie budynku nowym dachem. Kwestią drugorzędną, ale również mającą wpływ na warunki mieszkalne podopiecznych przytułku było położenie nowych podłóg i poprawienie ścian. Ponadto remontu wymagały również budynki gospodarcze ${ }^{75}$.

W aktach parafialnych nie ma wprawdzie informacji odnośnie do wyremontowania przytułku i pochodzenia funduszy na ten cel. Przypuszczać jednak można, iż zdołano doprowadzić budynek mieszkalny do stanu używalności, gdyż kolejny

${ }^{69}$ AMIT, sygn. 1/02/0014/1, Akta dotyczące Schroniska dla Starców w Garbowie.

${ }^{70}$ AAL, sygn. Rep 60 IV b 48, Akta Kościoła Parafialnego w Garbowie; J. Konefał, Z Mandżurii do Garbowa. Kaptańska droga ks. Dominika Przytuskiego. 1872-1942, (cz. IV), „Głos Garbowa", 3 (1999) s. 7-8.

${ }^{71}$ AMIT, Sygn. 1/02/0014/1, Akta dotyczące Schroniska dla Starców w Garbowie.

${ }^{72}$ Tamże.

${ }^{73}$ Tamże.

${ }^{74}$ M. Sobiesiak, Kartki z kroniki schroniska (przytułku), „Głos Garbowa”, 1-2 (2009) s. 11.

${ }^{75}$ Tamże. 
zapis w dokumentach przytułku wspomina o podłączeniu do niego elektryczności i budowie nowej drewnianej stodoły ${ }^{76}$.

Standard życia mieszkańców garbowskiego domu opieki był zatem niejednokrotnie wyższy od tego, jaki posiadali miejscowi chłopi. Mimo to, na kartach kroniki przytułku odczytać można ubolewanie z powodu braku kanalizacji, dostępu do bieżącej wody i urządzeń technicznych w budynku ${ }^{77}$.

\section{Pensjonariusze przytułku}

Mieszkańcami parafialnego przytułku w Garbowie byli głównie ludzie ubodzy, starzy, chorzy oraz niepełnosprawni ruchowo i intelektualnie obojga płci. Dolną granicą wieku pensjonariuszy było 21 lat $^{78}$.

Przytułek, zgodnie z wolą Janiny Studzińskiej, przeznaczony był przede wszystkim dla najuboższych mieszkańców gminy Garbów. Osoby te nie uiszczały żadnych opłat z tytułu opieki i utrzymania w przytułku. Koszty swojego pobytu w domu opieki ponosiły jedynie osoby zamożniejsze, które były samotne lub pozbawione wsparcia ze strony bliższej i dalszej rodziny ${ }^{79}$.

Wyżywienie podopiecznych składało się z trzech codziennych posiłków. Nadmienić trzeba, że przytułek posiadał własne produkty do przygotowania potraw. Były to nie tylko warzywa i owoce $z$ ogrodu i sadu, ale też przetworzone plony $\mathrm{z}$ pola oraz mięso i nabiał pochodzące z niewielkiej przydomowej hodowli zwierząt, głównie krów i prosiąt. Zasadne jest zatem stwierdzenie, że starano się zapewnić mieszkańcom przytułku dobrze zbilansowaną dietę ${ }^{80}$. Bywały oczywiście trudne sytuacje, gdy brakowało żywności. W takich wypadkach organizowano zbiórki artykułów spożywczych wśród miejscowej ludności ${ }^{81}$.

Liczba pensjonariuszy przytułku w latach 30 . XX w. była raczej stała. Opieką otaczano w nim dziesięć osób. Począwszy od zakończenia drugiej wojny światowej podopiecznych było coraz mniej ${ }^{82}$.

Jak wspomniano wyżej mieszkańcami garbowskiego przytułku mogły być wyłącznie osoby dorosłe. W historii tego domu opieki zdarzył się jednak jeden wyjątek. Sprawa dotyczyła dwóch sierot - Heleny i Janiny Wójcikównych ${ }^{83}$. Miały one wprawdzie bliskich krewnych, którzy deklarowali opiekę nad nimi, jednak nie zważając na ogromną więź siostrzaną, a jedynie na własne finanse i wygodę, zamierzali rozdzielić dziewczynki. Jedna z nich miała zamieszkać u wujostwa w Lublinie, a druga - w Warszawie. W przytułku natomiast przebywała ich ciotka. W takiej sytuacji proboszcz Dominik Przyłuski zdecydował o przyjęciu dziewczynek i roztoczeniu nad nimi opieki. Przydzielono im osobny pokój, który zaj-

\footnotetext{
${ }^{76}$ Tamże.

${ }^{77}$ Tamże.

${ }^{78}$ AMIT, Sygn. 1/02/0014/1, Akta dotyczące Schroniska dla Starców w Garbowie.

${ }^{79}$ Tamże.

${ }^{80}$ Tamże.

${ }^{81}$ Sobiesiak, Kartki z kroniki schroniska (przytułku), s. 11.

${ }^{82}$ Tamże.

${ }^{83}$ H. Kołtun, Sieroca dola, „Głos Garbowa”, 3 (2009) s. 8-9; Poleszak, Z okruchów pamięci,
} s. 10 . 
mowały wraz ze swoją ciocią począwszy od $1938 \mathrm{r}$. do $1947 \mathrm{r}^{84}$ Zadbano też o to, aby kontynuowały naukę w garbowskiej szkole powszechnej. Pod czujnym okiem prowadzących przytułek sióstr zakonnych, dziewczęta wyrosły na dobrze wychowane, odpowiedzialne i samodzielne kobiety, doskonale przygotowane do dorosłego życia ${ }^{85}$.

Warto jeszcze wspomnieć o Domu Noclegowym funkcjonującym przy przytułku. Zatrzymywali się w nim ludzie, którzy potrzebowali dachu nad głową na jedną lub kilka nocy. W latach wielkiego kryzysu gospodarczego, kiedy w Polsce wielu ludzi pozostawało bez pracy, ze wsparcia garbowskiej noclegowni korzystali głównie tzw. rajzerzy. Byli to bezrobotni, którzy przemierzali kraj w poszukiwaniu zatrudnienia. W garbowskiej noclegowni nigdy nie odmówiono pomocy takiej osobie ${ }^{86}$.

\section{Pracownicy przytulku}

Nadzór na przytułkiem podlegał kolejnym proboszczom garbowskiej para$\mathrm{fii}^{87}$. Sprawy administracyjne, opiekuńcze i wychowawcze powierzono natomiast bezhabitowym zakonnicom ze Zgromadzenia Sióstr Służek Najświętszej Maryi Panny Niepokalanej. Dom generalny tego zakonu znajdował się w Mariówce Opoczyńskiej ${ }^{88}$. Nie wiadomo, gdzie mieszkały siostry przed wybudowaniem przytułku. Pewnym jest natomiast, że posługiwały chorym i starym mieszkańcom Garbowa i okolic już od $1921 \mathrm{r}^{89}$

Z chwilą utworzenia domu opieki w 1932 r. siostry zamieszkały w budynku, gdzie mieścił się przytułek ${ }^{90}$. Tutaj też zorganizowały pracownię krawiecką, która stała się później podstawą do prowadzenia kursów kroju i szycia. Zgodnie z zapisami w kronice przytułku, w 1935 r. siostra Bronisława Dadej przyuczała do zawodu krawcowej dziesięć dziewcząt ${ }^{91}$.

Funkcję przełożonych garbowskiego przytułku pełniły kolejno siostry: Rozalia Góźdź (1932-1938), Bronisława Dadej (1938-1951), Antonina Dudziak (19511963) i Teresa Brygota (1964-1970) $)^{92}$.

Najważniejszym obowiązkiem zakonnic była oczywiście opieka nad mieszkańcami przytułku i dokładanie wszelkich starań, aby zapewnić im jak najlepsze warunki bytowe. Przy pomocy pensjonariuszy zajmowały się gospodarstwem

${ }^{84}$ Kołtun, Sieroca dola, s. 8-9.

${ }^{85}$ Poleszak, Z okruchów pamięci, s. 10.

${ }^{86}$ Suszkiewiczowa, Szukamy śladów, s. 13-15.

${ }^{87}$ AMIT, Sygn. 1/02/0014/1, Akta dotyczące Schroniska dla Starców w Garbowie.

${ }^{88}$ Tamże; H. Sobiesiak, Z Garbowa do Ząbkowic Śląskich, „Głos Garbowa”, 12 (2004) s. 6; M. Sobiesiak, Szukamy śladów tych, którzy przed nami trudzili się dla Polski i ludu Garbowa, Historia nauczycielka madrości, „Głos Garbowa”, 7 (2002) s. 4-5.

${ }^{89}$ Sobiesiak, Kartki z kroniki schroniska (przytułku),s. 11.

${ }^{90}$ AMIT, Sygn. 1/02/0014/1, Akta dotyczące Schroniska dla Starców w Garbowie.

${ }^{91}$ Kartki z kroniki schroniska (przytułku), s. 11; Sobiesiak, Z Garbowa do Ząbowic Ślaskich, s. 6; M. Sobiesiak, Nasza „mała Ojczyzna”, „Głos Garbowa”, 1-2 (2009) s. 10-11; Poleszak, Z okruchów pamięci, s. 10.

${ }^{92}$ Sobiesiak, Kartki z kroniki schroniska (przytułku), s. 11. 
i przygotowywaniem posiłków ${ }^{93}$. Ponadto prowadziły lekcje religii w szkołach prowadzonych na terenie gminy Garbów. Dbały też o wystrój miejscowego kościoła parafialnego, prały szaty liturgiczne itp. ${ }^{94}$ Zakonnice pracowały w przytułku do 1970 r. ${ }^{95}$

\section{Fundusze i sprawy administracyjne}

Środki pieniężne, z których pokrywano koszty funkcjonowania przytułku pochodziły głównie z datków składanych przez parafian. Niemniej jednak również proboszczowie garbowscy przeznaczali część swoich prywatnych dochodów na utrzymanie podopiecznych ośrodka. Budżet uzupełniany był ponadto wpłatami, jakie wnosili z tytułu opieki pensjonariusze przytułku oraz członkowie ich rodzin $^{96}$.

W dwudziestoleciu międzywojennym wszystkie przytułki prowadzono w oparciu o Rozporządzenie Prezydenta Rzeczypospolitej Polskiej z dnia 22 kwietnia 1927 roku o nadzorze i kontroli nad działalnością instytucji opiekuńczych. Ten akt prawny nakładał na proboszczów prowadzących zakłady opiekuńcze obowiązek składania do wydziału opieki właściwego urzędu wojewódzkiego lub urzędu miejskiego corocznych sprawozdań z działalności przytułku ${ }^{97}$. Niestety nie zachowała się tego rodzaju dokumentacja dotycząca funkcjonowania przytułku w Garbowie. W związku z tym niemożliwe jest dokładne opisanie wysokości budżetu tej instytucji, sposobów pozyskiwania funduszy pieniężnych i darów rzeczowych przeznaczanych na utrzymanie podopiecznych, a także procedur rozdziału dóbr materialnych i żywności między mieszkańców przytułku.

Przytułek w Garbowie funkcjonował do 1970 r. Krótka przerwa w jego działalności przypadła na lata drugiej wojny światowej. Nie zrezygnowano jednakże z prowadzenia Domu Noclegowego, gdzie potrzebujący pomocy zawsze mogli otrzymać jakieś wsparcie ${ }^{98}$.

\section{Zakończenie}

Instytucje opiekuńcze, jakie na przełomie wieków funkcjonowały przy garbowskim kościele parafialnym służyły najuboższym, osamotnionym i chorym mieszkańcom parafii, a później gminy Garbów. Zarówno w szpitalu parafialnym, jak i w przytułku opieką otaczani byli nie tylko ludzie dorośli, ale w uzasadnionych przypadkach także dzieci. Bez względu na epokę czy też sytuację polityczną i gospodarczą Polski proboszczowie współpracowali z miejscową ludnością w zakresie organizacji pomocy dla najbardziej potrzebujących, którzy nie potrafili samodzielnie pokonać życiowych trudności. Ogromne znaczenie dla rozwoju

\footnotetext{
${ }^{93}$ AMIT, sygn. 1/02/0014/1, Akta dotyczące Schroniska dla Starców w Garbowie.

${ }^{94}$ Suszkiewiczowa, Szukamy śladów, s. 13-15.

${ }^{95}$ Sobiesiak, Kartki z kroniki schroniska (przytułku), s. 11.

${ }^{96}$ Tamże.

${ }^{97}$ Rozporzadzenie Prezydenta RP z dnia 22 kwietnia 1927 roku o nadzorze i kontroli nad dziatalnościa instytucji opiekuńczych (Dz.U. $1927 \mathrm{nr} 40$ poz. 354).

${ }^{98}$ Sobiesiak, Kartki z kroniki schroniska (przytułku), s. 11.
} 
systemu opieki miało również zaangażowanie, jakie okazywali w tym względzie właściciele okolicznych majątków ziemskich, gdyż bez ich wsparcia finansowego pewne inicjatywy nigdy nie zostałyby zrealizowane.

Słowa kluczowe: szpital parafialny, przytułek, Garbów, opieka, działalność charytatywna.

\section{Źródla archiwalne}

\section{BIBLIOGRAFIA}

Archiwum Archidiecezji Lubelskiej, sygn. Rep 60 IV b 48, Akta Kościoła Parafialnego w Garbowie.

Archiwum Multimedialnej Izby Tradycji w Garbowie (AMIT), sygn. 1/02/0014/1, Akta dotyczące Schroniska dla Starców w Garbowie.

Archiwum Państwowe w Lublinie, sygn.35/115/0/2.6/8, Zespół: Rząd Gubernialny Lubelski, Akta szczegółowe tyczące się Szpitala w Garbowie.

Instrukcja dla dozorów parafialnych nad domami schronień z 12(24) czerwca 1943 roku, w: Zbiór przepisów administracyjnych Królestwa Polskiego, Wydział Spraw Wewnętrznych i Duchowych, cz. 3, Zakłady dobroczynne, t. 3. Warszawa 1866.

Theiner A., Vetera monumenta Poloniae et Lithuaniae, t. 2, Roma 1861.

Rozporządzenie Prezydenta RP z dnia 22 kwietnia 1927 roku o nadzorze i kontroli nad działalnością instytucji opiekuńczych (Dz.U. 1927 nr 40 poz. 354).

\section{Opracowania}

Chrzanowska A., Historia Garbowa, w: Wracamy w przeszłość..., cz. 1, red. R. Wójcik, Garbów 1999, s. 15-31

Chrzanowska A., Garbowscy dziedzice, „Głos Garbowa”, 12 (2000) s. 8-9.

Góralski Z., Szpitale na Lubelszczyźnie w okresie przedrozbiorowym, Część II, Lublin 1999, s. 33.

Kołtun H., Sieroca dola, „Głos Garbowa”, 3 (2009) s. 8-9.

Konefał J., Z Mandżurii do Garbowa. Kapłańska droga ks. Dominika Przyłuskiego. 18721942, (cz. IV), „Głos Garbowa”, 3 (1999) s. 7-8.

Nakonieczny W., Kronika bieżąca - Garbów, „Gazeta Lubelska. Pismo Codzienne Rolniczo-Przemysłowo-Handlowe i Literackie", 227 (1898) s. 2.

Nakonieczny W., Garbów, „Gazeta Lubelska. Pismo Codzienne Rolniczo-Przemysłowo -Handlowe i Literackie", 250 (1893) s. 2.

Poleszak I., Z okruchów pamięci... Historia przytułku parafialnego w Garbowie, „Głos Garbowa", 1-2 (2009) s. 10.

Sobiesiak M., Kartki z kroniki schroniska (przytułku), „Głos Garbowa”, 1-2 (2009) s. 11.

Sobiesiak M., Nasza „mała Ojczyzna”, „Głos Garbowa”, 1-2 (2009) s. 10-11.

Sobiesiak M., Szukamy śladów tych, którzy przed nami trudzili się dla Polski i ludu Garbowa, Historia nauczycielką mądrości, „Głos Garbowa”, 7 (2002) s. 4-5.

Sobiesiak H., Z Garbowa do Ząbkowic Śląskich, „Głos Garbowa”, 12 (2004) s. 6.

Stępniak H., Nasza mała ojczyzna - Garbowszczyzna, Garbów 2010.

Suszkiewiczowa M., Szukamy śladów tych, którzy przed nami trudzili się dla Polski i ludu Garbowa, Proboszcz - Dominik Przyłuski, „Głos Garbowa”, 7 (2002) s. 13-15. 
Wójcik R., Emil Bohdan Ignacy Broniewski, w: Siedziby ziemiańskie w krajobrazie ziemi garbowskiej, red H. Stępniak, Garbów 2008, s. 174-180.

Wójcik R., Historia Cukrowni „Garbów”, Lublin 2010.

Wójcik R., Historia parafii Garbów (odcinek I), „Głos Garbowa”, 1-2 (1991) s. 5.

Wójcik R., Historia parafii Garbów (odcinek II), „Głos Garbowa”, 3 (1991) s. 3-4.

Wójcik R., Historia parafii Garbów (odcinek III), „Głos Garbowa”, 4 (1991) s. 5.

Wójcik R., Historia parafii Garbów (odcinek VII), „Głos Garbowa”, 9 (1991) s. 5-6.

Wójcik R., Historia parafii Garbów (odcinek VIII), „Głos Garbowa”, 10 (1991) s. 4-5.

Wójcik R., Historia parafii Garbów (odcinek IX), „Głos Garbowa”, 11 (1991) s. 3-6.

internet

http:/diecezja.lublin.pl/dekanat,100273, Dekanat - garbowski. (dostęp: 14.03.2011r.)

\section{THE PARISH HOSPITAL AND THE SHELTER IN GARBÓW}

\section{Summary}

Into duties of parish priests not only a ministry was written down, but also organising the care for old, ill, poor and skipped parishioners. After the Trent Council which was held in latach1545-1563, they started forming parish hospitals, and on the XIX turning point and the 20th century shelters and houses of the refuge were made.

Into the history of the parish of Garbów activity of two protective institutions became part of: of the parish hospital and of the shelter called the Hostel for Old Men in Garbów.

The article is aimed portraying of the history these two institutions, from which every for many years served for the Garbów communities.

The first part of the article is regarding activity of the parish hospital. Based on observed parish and archival records and the available literature on the subject they presented here the standard of living of charges and funds of the hospital, and also to show the state of the residential building and ways of taking care of residents. Later an issue was introduced the foundation of hospital and other forms of financial supporting of hospitals.

In the second part of the article based on parish records and numerous memory articles placed in the local Press they portrayed history of the coming into existence and functioning of the shelter which was assigned for the poorest group the Garbów communities. They described the case of purchasing the building and adapting it at residential target and involving landowners in the matter of creating the shelter. They presented a living conditions of residents and duties of nuns which worked at this institution, and ways of financing activity of the nursing home were shown.

Keywords: parish hospital, shelter, Garbów, care, charity activity 